Western Washington University

Western CEDAR

$4-2013$

\title{
Developing Freedom: Thomas Jefferson, the State, and Human Capability
}

Johann N. Neem

Western Washington University, johann.neem@wwu.edu

Follow this and additional works at: https:// cedar.wwu.edu/history_facpubs

Part of the History Commons

\section{Recommended Citation}

Neem, Johann N., "Developing Freedom: Thomas Jefferson, the State, and Human Capability" (2013). History Faculty and Staff Publications. 16.

https://cedar.wwu.edu/history_facpubs/16

This Article is brought to you for free and open access by the History at Western CEDAR. It has been accepted for inclusion in History Faculty and Staff Publications by an authorized administrator of Western CEDAR. For more information, please contact westerncedar@wwu.edu. 


\title{
Developing Freedom: Thomas Jefferson, the State, and Human Capability
}

\section{Johann N. Neem, Western Washington University}

\begin{abstract}
Thomas Jefferson is often invoked as an advocate of limited government and a defender of individual rights. This article argues that rights were Jefferson's starting place. Jefferson also believed that American citizens should have opportunities to develop the capabilities necessary to enjoy the full use of their rights. Rather than thinking about Jefferson as progovernment or antigovernment, this article concludes that we must understand the particular kind of government Jefferson desired, the ends he had in mind, and why and how those ends differed from his Federalist predecessors. A better understanding of Jefferson's statecraft not only offers a new perspective on the relationship between government and rights in Jefferson's thought but also how and why Jeffersonians in power used the state to promote individual freedom.
\end{abstract}

There have been many Thomas Jeffersons. The time is ripe, however, for a new interpretation. For some time now, scholars of American political development have been urging researchers to "bring the state back in."

Research for this essay was supported by a fellowship from the Robert H. Smith International Center for Jefferson Studies at Monticello and a summer research grant from Western Washington University. Earlier drafts benefited from the comments of Max Edling, Richard John, Robert M.S. McDonald, Peter Onuf, Andrew O'Shaughnessy, John G. Richardson, and Brian Steele. I thank the editors and anonymous readers of this journal for their valuable criticism.

1. The classic essay is Theda Skocpol, "Bringing the State Back In: Strategies of Analysis in Current Research," in Bringing the State Back In, ed. Peter B. Evans, Dietrich Rueschemeyer, and Theda Skocpol (Cambridge: Cambridge University Press, 1985), 3-37. See also Karen Orren and Stephen Skowronek, The Search for American Political Development (Cambridge: Cambridge University Press, 2004); Michael Schudson, "The 'Public Sphere' and Its Problems: Bringing the State (Back) In," Notre Dame Journal of Law, Ethics, and Public Policy 8 (1994): 529-46. For Jefferson's era see Richard R. John, "Governmental Institutions as Agents of Change: Rethinking American Political Development in the Early Republic, 17871835," Studies in American Political Development 11 (1997): 347-80, and Spreading the News: The American Postal System from Franklin to Morse (Cambridge, MA: Harvard University Press, 1995); William J. Novak, "The Myth of the 'Weak' American State," American Historical Review 113 (2008): 752-72, and The People's Welfare: Law and Regulation in Nineteenth-Century America (Chapel Hill: University of North Carolina Press, 1996); Brian Balogh, A Government Out of Sight: The Mystery of National Authority in Nineteenth-Century America (Cambridge: Cambridge University Press, 2009), and "The State of the State Among Historians," Social Science History 27, no. 3 (fall 2003): 455-63; Mark L. Wilson, "Law and the American State, from the Revolution to the Civil War: Institutional Growth and Structural Change," in The Cambridge History of Law in America, vol. 2: "The Long Nineteenth Century," ed. Michael Grossberg and Christopher Tomlins (Cambridge: Cambridge University Press, 2008), 1-35.
Their insights have transformed our understanding of the role of government in the early national era, making it vital that we now rethink how American leaders understood the state's role.

Ideas matter to political development. Most scholars of post-Revolutionary American political development have focused on the results or influence of particular political institutions. ${ }^{2}$ Yet, as Mark Blyth recently argued, at times of institutional flux, ideas are vital to helping agents "plan and politic their way forward." While some theories of institutions focus on how institutions guide preexisting or shape new interests, Blyth responds that ideas also shape how people conceptualize their interests and design new institutions to achieve them. ${ }^{3}$

Blyth's focus was on the role of neoconservative ideas in shaping responses to the 1970 s economic

For overviews of the scholarship on Jefferson, see Francis D. Cogliano, Thomas Jefferson: Reputation and Legacy (Charlottesville: University of Virginia Press, 2006); Peter S. Onuf, "The Scholars' Jefferson," William and Mary Quarterly 50 (Oct. 1993): 671-99. For Jefferson's reputation in his own era, see Robert M. S. McDonald, "Thomas Jefferson's Changing Reputation as Author of the Declaration of Independence," Journal of the Early Republic (Summer 1999): 169-96.

2. See Richard R. John's paradigmatic work cited above. See also Robin Einhorn, American Taxation, American Slavery (Chicago: University of Chicago Press, 2006) for the effect of the institution of slavery on ideas about taxation and state power.

3. Mark Blyth, Great Transformations: Economic Ideas and Institutional Change in the Twentieth Century (Cambridge: Cambridge University Press, 2002), 10-11. Max Weber, of course, long ago argued that ideas could shape and reshape individuals' motives and institutional development. See also William Sewell, Logics of History: Social Theory and Social Transformation (Chicago: University of Chicago Press, 2004). 
crises, and the subsequent transformation of governing institutions in the 1980s, but one can extend his insight back into the 1790s. As Americans went about setting up a new regime, the form of all their institutions, from the family to the state, was in flux. New ideas were necessary to justify or to change inherited institutions for a republican society. Post-Revolutionary uncertainties led to a crisis in institutional legitimacy during the second half of the 1790s. Faced with a series of political and economic concerns, Jeffersonian Republicans condemned Federalist modes of governance they construed, not always fairly, as benefitting the few rather than the many. To Republicans, liberty seemed threatened by a government that used force during the Whiskey and Fries rebellions, and coercion via the Alien and Sedition acts in order to control the people. Republicans hoped to convince voters to reject the institutional innovations of Federalist leaders. $^{4}$

It is not enough to condemn; winning popular support for institutional change, Blyth makes clear, requires convincing people both about the failures of old institutions and the potential solution offered by new ones. Jeffersonians thus had to offer a new vision of the state that would better protect the people's liberties than the Federalist model. In doing so, Jeffersonians provided the intellectual foundations for a new kind of state. While it is beyond this essay's scope to examine the specific institutional outcomes of Jefferson's and his party's tenure in power, by better understanding Jefferson's ideas about the state, we will be better prepared to make sense of the state Jeffersonians built. ${ }^{5}$

In the 1780 s and 1790 s, Federalists sought to build a European-style fiscal-military state capable of sustaining public credit and protecting American national security and commerce in a hostile world. As much as possible within the American context, President George Washington and Treasury Secretary Alexander Hamilton hoped to emulate European political and fiscal institutions, as can be seen in their support for the Bank of the United States. Jeffersonians, worried that Federalists would use the state as a tool to serve elite rather than popular interests, successfully challenged these efforts. ${ }^{6}$

4. On the idea of the 1790 s as a decade of institutional crisis see, among many good sources, Balogh, Government Out of Sight, 53-111; Bruce Ackerman, The Failure of the Founding Fathers: Jefferson, Marshall, and the Rise of Presidential Democracy (Cambridge, MA: Harvard University Press, 2005); James Roger Sharp, American Politics in the Early Republic: The New Nation in Crisis (New Haven: Yake University Press, 1993; Stanley Elkins and Eric McKitrick, Age of Federalism: The Early American Republic 1788-1800 (New York: Oxford Univesity Press, 1993).

5. This essay strives to contribute to Andreas Kalyvas and Ira Katznelson's project to understand the context of liberalism in its early days as described in Liberal Beginnings: Making a Republic for the Moderns (Cambridge: Cambridge University Press, 2008).

6. Max M. Edling, A Revolution in Favor of Government: Origins of the U.S. Constitution and the Making of the American State (New York:
Yet Jefferson and his party should not be seen as simply a roadblock for state builders, especially since scholars since Henry Adams have emphasized the various ways in which Jefferson relied on government power to achieve his ends at both the state and national levels. ${ }^{7}$ Moreover, since ideas and institutions develop in a dynamic relationship with each other, understanding Jefferson will help us better conceptualize the ideas behind what Brian Balogh calls "a government out of sight." Republicans, Balogh concludes, developed a government to "enable rather than command" citizens. ${ }^{8}$

Jefferson did indeed seek a state that would enable rather than command. State development was always a means, never an end in itself. The end of Jefferson's statecraft was to enable people to enjoy their individual freedoms by engaging in the pursuit of happiness. This is an important point. Some scholars rightly argue that Jefferson was deeply committed to natural rights. ${ }^{9}$ We should not conflate Jefferson's commitment to rights with antistatism, however.

Oxford University Press, 2003), 227, writes that "while the Federalists may have won the battle over the Constitution, they lost the war over the political development of the United States. No powerful centralized state developed in America after the ratification of the Constitution."

7. Much work has explored the myriad ways in which Jefferson and Jeffersonians made use of state power. Examples include Henry Adams, History of the United States during the Administrations of Thomas Jefferson (New York: A \& C Boni 1930 [1889-91]); Leonard W. Levy, Jefferson and Civil Liberties: The Darker Side (Cambridge, MA: Harvard University Press, 1963); Merrill D. Peterson, Thomas Jefferson and the New Nation: A Biography (New York: Oxford University Press, 1970), 775-76; Forrest McDonald, The Presidency of Thomas Jefferson (Lawrences, KS: University Press of Kansas, 1976); Frank Bourgin, The Great Challenge: The Myth of Laissez-Faire in the Early Republic (New York: G. Braziller, 1989), chs. 7-8; Robert W. Tucker and David C. Hendrickson, Empire of Liberty: The Statecraft of Thomas Jefferson (New York: Oxford University Press, 1990); Gary J. Schmitt, "Thomas Jefferson and the Presidency," in Inventing the American Presidency, ed. Thomas E. Cronin (Lawrence, KS: University Press of Kansas, 1989), 326-46; John Lauritz Larson, Internal Improvement: National Public Works and the Promise of Popular Government in the Early United States (Chapel Hill: University of North Carolina Press, 2001); Peter S. Onuf and Leonard J. Sadosky, Jeffersonian America (Malden, MA : Blackwell Publishers, 2002), 139-71; Jeremy D. Bailey, Thomas Jefferson and Executive Power (Cambridge: Cambridge University Press, 2007); John Yoo, Crisis and Command: The History of Executive Power from George Washington to George W. Bush (New York: Kaplan, 2009), 99-143. In a recent essay examining the sources of American revenue and federal spending, Max M. Edling stresses continuity between the Federalist and Jeffersonian eras. See Edling, "The Origin, Structure, and Development of the American Fiscal Regime, 1789-1837," in Taxation, State, and Civil Society in Germany and the United States from the $18^{\text {th }}$ to the $20^{\text {th }}$ Century, ed. Alexander Nuetzenadel and Christoph Strupp (Baden-Baden: Nomos, 2007), 25-49.

8. Balogh, Government Out of Sight, 3, 121, 114.

9. Michel P. Zuckert, The Natural Rights Republic: Studies in the Foundation of the American Political Tradition (Notre Dame: University of Notre Dame Press, 1996), 27, argues that Jefferson believed that "the security of rights can be the only legitimate end of political society." See also David N. Mayer, The Constitutional Thought of Thomas Jefferson (Charlottesville: University Press of Virginia, 1994). 
Instead, Jefferson believed that to enjoy the freedoms that rights protected required constant government intervention in society and the economy. Otherwise, economic, political, and religious liberty would be empty promises. Jefferson would therefore have never understood the laissez-faire conception of political economy that emerged in the later nineteenth century and in whose name he is even today often invoked.

Jefferson's policies were shaped by his ideas about human nature. Like others of his era, Jefferson was influenced by the telos of faculty psychology. He believed that human nature was divided into distinct faculties-appetites and passions at the bottom, the moral sense and reason at the top. A good society was one that enabled citizens to pursue happiness, but happiness required developing one's faculties properly. A corrupt society, or corrupt policies, would undermine our innate morality and our reason and prevent happiness. ${ }^{10}$ Jefferson's statecraft thus sought to create contexts in which citizens could develop their faculties to the fullest. ${ }^{11}$

Jefferson made clear his commitment to this goal in his first inaugural address. Despite his famous claim that "free government is founded in jealousy, and not in confidence," his inaugural offered a capacious definition of government's obligations to citizens. $^{12}$ In contrasting his approach to that of his Federalist opponents, Jefferson made clear that the issue was not active versus inactive government but rather the ends pursued by government. While he supported a "wise and frugal government," he also believed that government must ensure that each of us receive "equal right to the use of our own faculties, to the acquisition of our own industry, to honor and confidence from our fellow-citizens, resulting not from birth, but from our actions and from their sense of them."13

This essay offers an interpretation of why Jefferson believed government was necessary to ensure all

10. For a discussion of Jefferson's ideas of human nature see Jean Yarbrough, American Virtues: Thomas Jefferson on the Character of a Free People (Lawrence, KS: University Press of Kansas, 1998). See also Lorraine Smith Pangle and Thomas Pangle, The Learning of Liberty: The Educational Ideas of the American Founders (Lawrence, KS: University Press of Kansas, 1993), 250-64.

11. Federalists were not inherently opposed to these goals. In might be argued that Federalists laid the foundations for Jefferson's project by encouraging young men to seek education and careers "beyond the farm," as J. M. Opal put it in his recent book. Federalists linked individual ambition to national glory, and urged young people to improve themselves in order to improve the nation. For better or for worse, Jefferson started from the opposite premise: the nation exists to serve individuals, not the other way around. J. M. Opal, Beyond the Farm: National Ambitions in Rural New England (Philadelphia: University of Pennsylvania Press, 2008).

12. Thomas Jefferson, "Draft of the Kentucky Resolutions" (Oct. 1798) in Thomas Jefferson: Writings, ed. Merrill D. Peterson (New York: Library of America, 1984), 454. Hereafter cited as TJW. 494.
Americans equal right to the use of their faculties and the products of their labor by analyzing Jefferson's proposed legal reforms for Virginia's government following the Revolution. Part of a three-person committee appointed by the state legislature to revise the laws, Jefferson argued that since "many of the laws which were in force during the monarchy being relative merely to that form of government, or inculcating principles inconsistent with republicanism," Virginia legislators recognized the need "to revise the whole."14

Looking back on the committee's proposals during his retirement, Jefferson observed in his unpublished "Autobiography" that he considered " 4 of these bills, passed or reported, as forming a system by which every fibre would be eradicated of antient or future aristocracy; and a foundation laid for a government truly republican." The four specific goals were the repeal of entail, the abolition of primogeniture, the protection of religious liberty, and the public provision of education to all Virginians. Jefferson believed his proposals, despite requiring active government, "would be effected without the violation of a single natural right of any one individual citizen." 15

My approach to Jefferson draws from and moves beyond the three camps that have long dominated Jefferson interpretation: the republican, liberal, and populist. All three have their finger on part of the truth, but all miss the larger goals of Jefferson's statecraft. Republican interpretations tend to emphasize the value Jefferson placed on active, virtuous citizenship. Jefferson did certainly value citizenship, but citizenship was always a means to the end of protecting liberty. Being a good citizen was not, as republicanism implied, the end of human life; it was necessary to protect liberty from corrupt leaders. ${ }^{16}$

Liberal interpretations, on the other hand, emphasize Jefferson's commitment to individual rights and his progressive, forward-looking conception of

14. Jefferson, Notes on the State of Virginia (1787), Query 14, in TJW: 263

15. Jefferson, "Autobiography," in TJW: 44-45.

16. John M. Murrin, "Can Liberals Be Patriots? Natural Right, Virtue, and Moral Sense in the America of George Mason and Thomas Jefferson," in Natural Rights and Natural Law: The Legacy of George Mason, ed. Robert P. Davidow (Fairfax, VA: George Mason University Press, 1986), 35-65; Garrett Ward Sheldon, The Political Philosophy of Thomas Jefferson (Baltimore: Johns Hopkins University Press, 1991). J. G. A. Pocock, The Machiavellian Moment: Florentine Political Thought and the Atlantic Republican Tradition (Princeton, NJ: Princeton University Press, 1975), 532-45; Lance Banning, The Jeffersonian Persuasion: Evolution of a Party Ideology (Ithaca: Cornell University Press, 1978); Drew McCoy, The Elusive Republic: Political Economy in Jeffersonian America (Chapel Hill: University of North Carolina Press, 1980); John M. Murrin, "The Great Inversion, or Court versus Country: A Comparison of the Revolution Settlements in England (1688-1721) and America (1776-1816)," in Three British Revolutions: 1641, 1689, 1776, ed. J. G. A. Pocock (Princeton, NJ: Princeton University Press, 1980), 368-453. More generally see Daniel T. Rodgers, "Republicanism: The Career of a Concept," Journal of American History 79 (June 1992): 11-38. 
history. These scholars argue that Jefferson favored protecting individuals from government ("negative liberty") in order to sustain their natural rights. ${ }^{17}$ The most prominent advocate for a liberal reading of Jefferson has been Joyce Appleby. ${ }^{18}$ Appleby challenges Henry Adams's argument that Jefferson as president made greater use of state power than his Federalist predecessors. "Nothing could be further from the truth," Appleby writes. ${ }^{19}$ Instead, to Appleby, Jefferson's philosophy sought to enable individuals, "so long alienated from their true nature," to rediscover it. Quoting Jefferson's contemporary James Duane, Appleby describes Jefferson's political philosophy as that of a "rubber-off of dust." Jefferson, in other words, challenged inherited ideas about the privileges of monarchs, aristocrats, and priests in order to recover people's natural equality and rights.

Although Appleby understands Jefferson's end she captures only one half of Jefferson's means-the rubbing off. Once Jefferson finished rubbing off history's accretions, however, he believed that the state must build up individuals' capabilities to take advantage of the freedoms the Revolution secured. ${ }^{20}$ As Robert Wiebe has written: "Building something new early in the $19^{\text {th }}$ century depended first on breaking

17. As the debate between republicans and liberals wore on, scholars rightly noted that Jefferson drew on both traditions at different times and for different purposes, suggesting that the two traditions were not mutually exclusive. See, among many sources, Kalyvas and Katznelson, Liberal Beginnings; Sheldon, Political Philosophy of Thomas Jefferson.

18. Appleby has made this claim in several places. See Capitalism and a New Social Order: The Republican Vision of the 1790s (New York: New York University Press, 1984); "What Is Still American in the Political Philosophy of Thomas Jefferson?" William and Mary Quarterly (April 1982): 287-309; "Jefferson and His Complex Legacy" in Jeffersonian Legacies, ed. Peter S. Onuf (Charlottesville: University Press of Virginia, 1993), 1-16; "Thomas Jefferson and the Psychology of Democracy" in The Revolution of 1800: Democracy, Race, and the New Republic, ed. James Horn, Jan Lewis, and Peter S. Onuf (Charlottesville: University of Virginia Press, 2002), 155-72.

19. Joyce Appleby, Thomas Jefferson (New York: Times Books, 2003), 32. See also Robert M. S. McDonald, "The (Federalist?) Presidency of Thomas Jefferson," in A Companion to Thomas Jefferson, ed. Francis D. Cogliano (Malden, MA: Wiley-Blackwell, 2011), 164-83.

20. Appleby and Duane quoted in Appleby, "Thomas Jefferson and the Psychology of Democracy," 161. It might be added that Jefferson did not think that people were naturally capable of selfgovernment even if they had a natural right to it. He believed that culture and history played vital roles. To Jefferson, therefore, it would not be enough to return to natural man; one then had to build up. He thus concluded during the French Revolution that "some preparation seems necessary to qualify the body of a nation for self-government" (TJ to Dr. Joseph Priestley, Nov. 29, 1802, in The Works of Thomas Jefferson, ed. Paul L. Ford, 12 vols. (New York: G. P. Putnam's Sons, 1904-05), 9: 404-6 [hereafter cited as TJF.]). Similarly, Jefferson concluded in 1803 that French Louisianans "are as yet as incapable of self government as children." (TJ to DeWitt Clinton, Dec. 2, 1803, TJF 10:54-55). On these points see Brian Douglas Steele, Thomas Jefferson and American Nationhood (Cambridge: Cambridge University Press, 2012). down something old: the prerequisite to construction was destruction." 21

Populist interpretations of Jefferson have been less central to scholarly conversations but more influential in American politics. Populists invoke Jefferson's commitment to equality and, thus, to the wide distribution of property. ${ }^{22}$ Populists rightly note that Jefferson believed that ordinary people should receive a fair return on their labor and that land and capital be distributed widely rather than concentrated in the hands of a privileged few. What they miss, however, is that in Jefferson's fight on behalf of "the people" against "aristocracy," he always sought to promote individual freedom, meaning a world in which each citizen could develop his (and, to an extent, her) faculties.

In short, Jefferson believed in a state that not just rewarded and unleashed individual initiative and creativity, like that which James Willard Hurst described in his classic essay on American law in the early national era, but one that also produced people capable of being creative and taking initiative. ${ }^{23}$ Being a self-made man, Jefferson recognized, requires being given the resources one needs to engage in

21. Robert H. Wiebe, Self-Rule: A Cultural History of American Democracy (Chicago: University of Chicago Press, 1995), 27.

22. Recently, there have been some efforts to invoke the populist Jefferson. See Claudio Katz, "Thomas Jefferson's Liberal Anticapitalism," American Journal of Political Science 47 (Jan. 2003): 1-17; Michael Hardt, "Jefferson and Democracy," American Quarterly (2007): 41-78. See also Sean Wilentz's recent Rise of American Democracy: Jefferson to Lincoln (New York: Norton, 2005); James L. Huston, Securing the Fruits of Labor: The American Concept of Wealth Distribution, 1765-1900 (Baton Rouge, LA: Louisiana State University Press, 1998). Richard K. Matthews, Radical Politics of Thomas Jefferson: A Revisionist View (Lawrence, KS: University Press of Kansas, 1984), offers a sophisticated understanding of Jeffersonian populism because he recognizes that Jefferson's distributive schemes and his fight against interests were always to promote individual freedom and happiness. In addition, students of Jefferson's conception of executive power have noted that Jefferson helped lay the foundations for the imperial presidency by linking the president's exercise of his powers to the people themselves. In this view, expressed most recently by Bailey, Thomas Jefferson and Executive Power, and Yoo, Crisis and Command, 126-36, the president portrays himself as an agent of the people, creating a populist justification for a broad reading of executive power. On this point, see also Sidney A. Milkis and Michael Nelson, The American Presidency: Origins and Development, 1776-1990 (Washington, DC: CQ Press, 1990), 87-106; Ralph Ketcham, Presidents above Party: The First American Presidency, 1789-1829 (Chapel Hill: University of North Carolina Press, 1984); Ackerman, Failure of the Founding Fathers. Peter S. Onuf, Jefferson's Empire: The Language of American Nationhood (Charlottesville, VA: University Press of Virginia, 2000), moves beyond the populist perspective. Onuf explores why Jefferson believed that the common good would emerge naturally from the people's will. Onuf suggests that Jefferson's vision was ultimately cosmopolitan in scope. He imagined a world of self-governing republics held together by citizens' natural ties of affection. Onuf offers a sophisticated understanding of the intellectual foundations for Jefferson's faith in popular democracy.

23. J. Willlard Hurst, Law and the Conditions of Freedom in the Nineteenth-Century United States (Madison, WI: University of Wisconsin Press, 1956). 
self-making. And, to Jefferson, this meant using the state to create a society in which ordinary people could develop their faculties in order to pursue their happiness. $^{24}$

\section{THE REPEAL OF ENTAIL AND PRIMOGENITURE}

In every area of life, Jefferson argued that, first, Americans must remove the accretions of history, those institutions that have limited humanity's natural rights, and then must follow through by helping people develop the capability to take advantage of their newly held rights. This was particularly true in political economy. To Jefferson, a free market was one in which individuals could make real choices about their economic lives and had real opportunities to make good their economic potential. This required removing the Old World's limits on free markets-entail, primogeniture, and mercantilism-and then endowing individuals with the means to enjoy their economic freedom-access to capital and, through internal improvements and free trade, access to markets. For every piece of dust rubbed off, Jefferson articulated government's responsibility to do something positive. Jefferson did not believe government should do everything. He believed in markets and was committed to limiting both taxation and debt. He believed that public debt not only led to high taxes-thus taking from citizens what they have earned-but it tended to benefit elite money holders by redistributing wealth and political influence upward. In addition, public debt was often used to fund wars, and wars, in turn, led to more debt, creating a vicious cycle that Jefferson hoped to avoid. Hence he exerted effort as president to cut both the debt and military expenditures. ${ }^{25}$ Moreover, Jefferson believed that political power should be exercised as locally as possible. Power should move upfrom the local "ward republic" to the state to the nation-only when necessary for the common good. ${ }^{26}$ But, surprisingly, more often than not, Jefferson found it necessary to use state power to implement his vision of a free society.

Ultimately, Jefferson's economic policies were designed to create and sustain an agrarian republic. Jefferson believed, as Jean Yarbrough writes, that "whether a man is his own master or labors for another; whether he tills the soil, performs simple repetitive operations in the workshop, or speculates in markets has implications that reach beyond the purely economic." 27 Jefferson famously declared

24. From a theoretical perspective, see Elizabeth S. Anderson, "What is the Point of Equality?" Ethics 109 (Jan. 1999): 287-337.

25. Max Edling, "Political Economy," in A Companion to Thomas Jefferson, ed. Francis D. Cogliano, chap. 27.

26. Yarbrough, American Virtues, 102-52; Matthews, Radical Politics.

27. Yarbrough, American Virtues, 55. that yeomen are the "chosen people of God" because, free of the corrupting influences of cities, industry, and dependence on others, they could develop their innate moral and reasoning faculties. Both more primitive and more advanced commercial societies, on the other hand, favored the few over the many, and the passions over reason and moral sense. $^{28}$

Jefferson's first proposed reform was to eliminate entails and primogeniture, both devices used by Old World aristocrats to maintain their power and privilege. ${ }^{29}$ In the Old World, aristocracies consolidated their control over land and property across generations, and they parlayed wealth into political power. Entails allowed elites and such institutions as endowed charities and the established church to lock up land beyond the public's reach, sustaining a minority's control over society's resources and denying others the opportunity to engage in the pursuit of happiness. Primogeniture ensured that landed property was passed on whole from one generation to the next, allowing families to consolidate and expand wealth over time. Both devices limited the ability of the current generation to make full use of their individual liberties. Jefferson, on the other hand, believed " that the earth belongs in usufruct to the living." 30 Only those currently living could lay claim to the land and its bounty. The current generation has a natural right to society's productive resources. ${ }^{31}$

During a 1785 walk in Fontainebleau, France, Jefferson was struck by how unequally wealth was distributed, and how hardworking peasants received so little return on their efforts. The reason, he wrote to James Madison, was that "the property of this country is absolutely concentrated in a very few hands" who "employ the flower of the country as servants." The

28. TJ, Query 19, Notes on the State of Virginia, TJW: 290-91; TJ to William Ludlow, Sept. 6, 1824, TJW: 1496-97. See Yarbrough, American Virtues, 55-101. See also Edling, "Political Economy"; Herbert Sloan, Principle and Interest: Thomas Jefferson and the Problem of Debt (New York: Oxford University Press, 1995); McCoy, The Elusive Republic; Huston, Securing the Fruits of Labor; Steele, Jefferson and American Nationhood.

29. The importance of generations in Jefferson's thought is emphasized in Peter S. Onuf, The Mind of Thomas Jefferson (Charlottesville, VA: University of Virginia Press, 2007), 169-78; Hardt, "Jefferson and Democracy"; and Matthews, Radical Politics.

30. TJ to James Madison, Sept. 6, 1789, TJW: 959-64, at 959. See also TJ to John Wayles Eppes, June 24, 1813, TJW: 1280-86; TJ to Samuel Kercheval, July 12, 1816, TJW: 1395-1403. My understanding of Jeffersonian political economy depends on Huston, Securing the Fruits of Labor. See also Onuf, Mind of Thomas Jefferson, 110-17; Hardt, "Jefferson and Democracy"; Mayer, Constitutional Thought, 302-8; Katz, "Jefferson's Liberal Anticapitalism"; Bourgin, Great Challenge, chaps. 7-8; Sloan, Principle and Interest; Appleby, Capitalism and a New Social Order, McCoy, The Elusive Republic; Charles Miller, Jefferson and Nature: An Interpretation (Baltimore: Johns Hopkins University Press, 1988), 199-216.

31. For a discussion of the impact of Jefferson's entail and primogeniture reforms, see Holly Brewer, "Entailing Aristocracy in Colonial Virginia: 'Ancient Feudal Restraints' and Revolutionary Reform,” William and Mary Quarterly 54 (April 1997): 307-46. 
problem was that the hardworking poor were robbed of the opportunity to own land and produce wealth from their labor. The only answer therefore was to ensure that every generation starts anew. "I am conscious that an equal division of property is impracticable," Jefferson acknowledged, "but the consequences of this enormous inequality producing so much misery to the bulk of mankind, legislators cannot invent too many devices for subdividing property." ${ }^{2}$

Jefferson admitted that the "natural affections of the human mind" objected to having one's land distributed to outsiders, but rather than permit landed and other property, including slaves, to be transferred whole to the next generation, the law should mandate "the descent of property of every kind therefore to all the children, or to all the brothers and sisters, or other relations in equal degree" so that property is subdivided every generation. Jefferson also supported a progressive land tax as a disincentive to accumulate too much wealth: "Another means of silently lessening the inequality of property is to exempt from taxation below a certain point, and to tax the higher portions of property in geometrical progression as they rise." ${ }^{33}$

Even as Jefferson concluded that one could have too much land, he did not seek absolute equality because he believed that both property and its limits were premised on the natural right to gain the legitimate fruits of one's labor. While one could not take from people what they earned by the sweat of their brows, no one had a right to more than they had earned. Regardless of present inequalities, however, Jefferson was adamant that "the law of nature" mandated redistributing wealth between generations. ${ }^{34}$ There was a point at which inequality was no longer justifiable: "Whenever there are in any country uncultivated lands and unemployed poor, it is clear that the laws of property have been so far extended as to violate natural right." Property, Jefferson believed, following John Locke, grew out of mixing one's labor with the land. Aristocrats had more land than they could use productively, while others were denied the ability to gain access to land: "the earth is given as a common stock for man to labor and live on. If for the encouragement of industry we allow it to be appropriated, we must take care that other employment be provided to those excluded from the

32. TJ to James Madison, Oct. 28, 1785, TJW: 840-43.

33. Ibid. See also TJ to George Washington, Nov. 14, 1786, The Papers of Thomas Jefferson, 34 vols. to date (Princeton, 1950- ), 10: 531-33 (hereafter cited as TJP).

34. On these points, see TJ to Joseph Milligan, April 6, 1816, in Andrew A. Lipscomb and Albert Ellery Bergh, eds., The Writings of Thomas Jefferson (Washington, DC: Thomas Jefferson Memorial Association of the United States, 1905), XIV: 466 (herafter cited as Lipscomb). I thank Joyce Appleby for bringing this letter to my attention. For a discussion of Jefferson's theory of labor, see Huston, Securing the Fruits of Labor. appropriation. If we do not, the fundamental right to labor the earth returns to the unemployed." 35 The wealthy have no right to more land than they can use when the poor are denied enough capital to translate their potential economic freedom into actual economic freedom. Jefferson was clearly concerned not just with the status of being free but with ensuring Americans the capability to use their economic freedom.

Jefferson's concerns about land were more than just economic. He also believed that the wide distribution of land and wealth enabled the broad distribution of political power. Owning land gave farmers the capability to exercise their political independence rather than to be beholden to the "caprice" of customers or more powerful people. ${ }^{36}$ The wide distribution of wealth would not just promote economic freedom but protect democracy itself.

Jefferson was equally committed to breaking down trade barriers that, he believed, prevented Americans from bringing their goods to market. Both before and during his presidency Jefferson believed that the federal government must promote free trade with Europe and Europe's Caribbean colonies. Adam Smith argued in his 1776 Wealth of Nations that tariffs and monopolies protected special interests at the majority's expense. Free trade would serve the good of all participant nations. Jefferson thus urged all nations "to throw open the doors of commerce, and to knock off all its shackles, giving perfect freedom to all persons for the vent of whatever they may chuse to bring into our ports, and asking the same in theirs. ${ }^{37}$ As president, Jefferson purchased the Louisiana Territory to ensure American farmers access to the Mississippi River, engaged in war with the Barbary pirates, and, in perhaps the largest exercise of state power other than war, embargoed all American shipping in order to force France and Britain to open their ports to American goods. Each action was taken to facilitate Americans' substantive freedoms, to enhance their capability to engage in market activity.

Jefferson's reforms concerning entails, primogeniture, and free trade can be seen as liberal-they sought to eradicate existing barriers preventing people from enjoying their natural rights. ${ }^{38}$ But the process would be incomplete if all Virginia or America did was remove existing barriers. To Jefferson, political and economic freedoms were meaningless unless each citizen had access to the resources-the capital—to take advantage of economic opportunities. $290-91$

35. TJ to James Madison, Oct. 28, 1785, TJW: 840-43, at 841-42. 36. Jefferson, Query 19 in Notes on the State of Virginia, TJW:

37. Jefferson, Notes on the State of Virginia, Query 22, TJW: 300. See Appleby, Capitalism and a New Social Order, Onuf and Sadosky, Jeffersonian America, 139-71.

38. For such a reading, see Mayer, Constitutional Thought, 74-83. 
No one is self-sufficient, Jefferson believed. Farmers cannot be independent if they do not own their own land. And even if they do own their land, farmers must be able to get their crops to market. To solve both problems, Jefferson turned to government.

The first step was for government to ensure every Virginian access to land. In his draft constitution for Virginia, Jefferson proposed that "every person of full age neither owning nor having owned [fifty] acres of land, shall be entitled to an appropriation of [fifty] acres or to so much as shall make up what he owns or has owned [ fifty] acres in full and absolute dominion. And no other person shall be capable of taking an appropriation." This land would come from the existing public domains as well as from land to be purchased from Native Americans. ${ }^{39}$ As president, Jefferson would extend this policy from Virginia to the nation by purchasing Louisiana from France and seeking to purchase as much land from Indians as possible to distribute to poor white Americans.

Jefferson meant what he said. In 1779, he proposed a bill for establishing a Land Office to distribute Virginia's western lands to settlers. The bill set up four categories of rights by which people could claim access to western land. The first, importation rights, revived the colonial practice of granting headrights. The second, native rights, was the most radical and the most important. It granted all native Virginians a right to seventy-five acres of western land upon marriage. In other words, it distributed lands held in common to poor individuals. The third, military rights, concerned land bounties granted to Revolutionary war soldiers and officers. The final category, treasury rights, dealt with purchases made through the proposed Land Office.

The Virginia House did not support Jefferson's program, however. Instead, in Merrill D. Peterson's words, it "massacred Jefferson's plan." It eliminated grants to immigrants and native-born Virginians. In addition, the House required purchasers of any land to obtain a warrant from the Register of the Land Office in Williamsburg. Jefferson's bill, in contrast, would have allowed purchases under 400 acres to be authorized by local county courts. According to the final bill, poorer farmers would now have to travel to Williamsburg-no easy feat in those daysto purchase land rather than being able to purchase land locally. Neither Jefferson's bill nor the final act limited the total number of acres an individual could purchase, reminding us that Jefferson's goal was relative equality and access to capital, not absolute equality. The final act favored speculators over small proprietors and destroyed Jefferson's hope that

39. Jefferson, "Draft Constitution for Virginia" (June 1776), TJW: 343 .
Virginia would provide every immigrant and young person access to landed capital. ${ }^{40}$

Land was not enough. The state needed to create the infrastructure that would allow farmers to get their crops to domestic and foreign markets. As president, Jefferson supported federally funded internal improvements. He wanted the federal government to help build turnpikes and canals and to improve harbors. This was a position he came to after reflection, and probably under the influence of his Treasury Secretary Albert Gallatin, who gave expression to these sentiments in his 1808 Report on Roads, Canals, Harbors, and Rivers. ${ }^{41}$

At first, incoming President Jefferson was hesitant about using federal power to promote internal improvements. After all, he had just barely won the presidency on a platform opposing the Federalists for their supposed abuse of federal power. In $1802 \mathrm{Jef}-$ ferson reminded his treasury secretary of his "doubts, or rather convictions, about the unconstitutionality of the act for building piers in the Delaware," continuing that allowing the federal government to get involved in such matters would "lead to a bottomless expense, \& to the greatest abuses." Even then he remained hopeful that a way would be found to use the federal state to build infrastructure. He suggested that even if "the power to regulate commerce" does not authorize such expenditures, perhaps "the power to provide and maintain a navy, is a power to provide receptacles for it." 42

40. Discussion and quotes from Merrill D. Peterson, Thomas Jefferson and the New Nation: A Biography (New York, 1970), 121-22. See also "Editorial Note," TJP 2: 133-38.

41. United States Department of the Treasury, Report of the Secretary of the Treasury, Albert Gallatin, on the subject of public roads $\mathcal{E}^{\circ}$ canals (reprint, New York: A. M. Kelley, 1968). See discussion in Bourgin, Great Challenge, chaps. 8-9; Thomas K. McCraw, The Founders and Finance: How Hamilton, Gallatin, and other Immigrants Fostered a New Economy (Cambridge, MA: Harvard University Press, 2012). Most industrializing societies in the nineteenth and twentieth centuries relied on an active state to promote economic growth, in contrast to the "libertarian" orthodoxy of many global economic institutions today. See Ha-Joon Chang, Kicking Away the Ladder: Development Strategy in Historical Perspective (London: Anthem, 2002); Dani Rodrik, The Globalization Paradox: Democracy and the Future of the World Economy (New York: Norton 2011).

42. TJ to Albert Gallatin, Oct. 13, 1802, TJF 9: 398-99. See also TJ to Thomas Digges, June 19, 1788, TJP 13: 260-61. For a discussion of Jeffersonian Republicans and internal improvements, in addition to Larson, Internal Improvement, see Larson, "Jefferson's Union and the Problem of Internal Improvement," in Jeffersonian Legacies, ed. Peter S. Onuf (Charlottesville: University Press of Virginia, 1993), 340-69, esp. 359-64; Bourgin, Great Challenge, chap. 8; Richard E. Ellis, "The Political Economy of Thomas Jefferson," in Thomas Jefferson: The Man, His World, His Influence, ed. Lally Weymouth (New York: G. P. Putnam, 1973), 81-95; Joyce O. Appleby, "The 'Agrarian Myth' in the Early Republic," in Liberalism and Republicanism in the Historical Imagination (Cambridge, MA: Harvard University Press, 1992), 253-76; Joseph H. Harrison, Jr., "Sic et Non: Thomas Jefferson and Internal Improvement," Journal of the Early Republic 7 (Winter 1987): 335-49; Onuf and Sadosky, Jeffersonian America, 131-70; and, most recently, Balogh, Government Out of Sight, 112-50. 
Jefferson's worry that the federal government was unauthorized to build internal improvements, and his fear that the power, if authorized, would be abused, never went away. Yet Jefferson's tone soon changed. During the rest of his presidency, he consistently supported federally funded internal improvements if the Constitution could be amended to permit them. Given his debates with Hamilton over the constitutionality of a national bank and his hostility to Hamilton's broad reading of the "necessary and proper" clause, Jefferson believed that to pursue federally funded internal improvements required some sort of specific Constitutional authorization.

Jefferson's concerns about constitutionality, however, did not undermine his conviction that federally funded internal improvements served the common good. By 1805 Jefferson wrote Gallatin excitedly that the "increase of [federal] revenue ... hastens the moment of liberating our revenue, and of permitting us to begin upon canals, roads, colleges, \&c." ${ }^{43}$ In his sixth annual message to Congress, Jefferson came out publicly in favor of internal improvements. While some Jeffersonians advocated reducing federal expenditures now that the government had "a surplus revenue," Jefferson proposed more spending. He urged Congress to apply federal revenue to "the great purposes of public education, roads, rivers, canals, and such other objects of public improvement as it may be thought proper to add to the constitutional enumeration of federal powers. ${ }^{44} \mathrm{He}$ repeated this request in his 1808 annual message, but this time he left it up to Congress to decide whether internal improvements could be funded "under the powers which Congress may already possess, or such amendment of the constitution as may be approved by the States?" ${ }^{45}$ As of 1808 , Jefferson chose to focus primarily on internal improvements and only secondarily on the constitutional question.

In private, Jefferson also advocated spending federal money for internal improvements. In $1807 \mathrm{Jef}-$ ferson expressed frustration at Congress's unwillingness to spend money on internal improvements and a national university. He hoped a constitutional amendment would be quickly approved. He recognized how difficult it was for many legislators to understand the importance of internal improvements and public education to individual freedom, reminding his correspondent of the "snail-paced gait for the advance of new ideas on the general mind, under which we must acquiesce."

43. TJ to Albert Gallatin, May 29, 1805, TJF 10: 146-47. See also TJ to Gallatin, Aug. 31, 1806, TJF 10: 284-86.

44. Jefferson, "Sixth Annual Message," Dec. 2, 1806, TJW: 52431 , at 529-30.

45. Jefferson, "Eighth Annual Message," Nov. 8, 1808, TJW: $543-49$, at 549 .

46. TJ to Joel Barlow, Dec. 10, 1807, TJF 10: 529-30. convinced that economic freedom depended on building a market accessible to all Americans. In 1811 he waxed poetic about the ways in which federal spending could unleash the potential of individuals: "Our revenues once liberated by the discharge of the public debt, and it's surplus applied to canals, roads, schools, \&c., and the farmer will see his government supported, his children educated, and the face of his country made a paradise by the contributions of the rich alone, without his being called on to spare a cent of his earnings." ${ }^{47}$

Jefferson's commitment to internal improvements did not wane during retirement even as his latter years were marked by a growing commitment to states' rights. ${ }^{48}$ Unlike his years as president, however, Jefferson now focused on constitutional questions first and internal improvements second. He thus aligned his support of expanding federal power to build a free market with his states' rights position. In 1812, for example, he expressed support for James Madison's veto of an internal improvements bill passed by both houses of Congress, but concluded optimistically that a constitutional amendment "will be unanimously conceded, \& will be a better way of obtaining the end, than by strained constructions." ${ }^{49}$ Jefferson did not consider the primary difference between the National Republicans under John Quincy Adams and the emerging Democratic opposition to be over federal activism, but rather over constitutional construction. ${ }^{50}$

By destroying the Old World's methods of hording economic capital—entails, primogeniture, and trade restrictions-and then developing the economic opportunities of ordinary people by ensuring the wide distribution of land and by publicly funded internal improvements, the Virginia and federal governments would ensure Americans both the right to participate in free economic activity and the capability to do so. Throughout his correspondence and public statements, Jefferson argued that without an active, engaged state the freedoms of the free market would be meaningless.

47. TJ to Dupont de Nemours, Apr. 15, 1811, TJF 11: 196-206, quoted at 203-4. See also TJ to Baron F. H. Alexander von Humboldt, Mont. June 13, 1817, TJF 12: 68-70. The reference to "the rich alone" is a reminder that the federal government's main source of revenue was taxing imported luxuries-a consumption tax on the rich.

48. See Onuf, Jefferson's Empire, for Jefferson's evolving ideas about federalism. See Harrison, "Sic et Non" for a discussion of Jefferson's changing attitude in his later years.

49. TJ to George Ticknor, May 1817, TJF 12: 58-59. See also TJ to Albert Gallatin, Mont. June 16, 1817, TJF 12: 70-74.

50. See TJ to Robert J. Garnett, Feb. 14, 1824, TJF 12: 341-43; TJ to Edward Livingston, Apr 4, 1824, TJF 12: 348-51; TJ to James Madison, Dec. 24, 1825, TJF 12: 416-18; TJ to William B. Giles, Dec. 26, 1825, TJF 12: 424; TJ to William F. Gordon, Jan. 1, 1826, TJF 12: 429-31; TJ to James Madison, Jan. 2, 1826, TJF 12: 431-32. 


\section{EDUCATION}

Jefferson was one of America's most outspoken advocates of public education. He believed that in a free society the state must provide children the resources necessary to develop their faculties. Historians have long recognized the importance Jefferson placed on education to prepare citizens for self-government. ${ }^{51}$ Jefferson should not be lumped together with such other educational reformers as Benjamin Rush, however. To Rush, civic education was designed to correct the people, to transform them into "republican machines." Jefferson instead believed that public education must build on human nature. More important, Jefferson's education goals were not solely public in orientation. He was equally concerned that public education provide Virginians the skills and knowledge they would need to pursue their private happiness in the market and in life. ${ }^{52}$

Americans, like Europeans, had long been denied both the right and the capability to engage in their public responsibilities and private pursuits of happiness, Jefferson believed. If knowledge and skills were prerequisites to making decisions about one's own life and to sustaining republican government, in Europe, and in New England too, the clergy and the wealthy elite controlled access. To Jefferson, a world dominated by an aristocracy of knowledge posed two threats to individual liberty. First, it threatened republican government by denying people the ability to be effective citizens and to protect their liberties. Second, it prevented people from engaging in their own pursuits of happiness. Jefferson's educational proposals thus had two elements. The first was to provide all white citizens-at the elementary level Jefferson included girls-with a basic education. The second was to take the most capable young boys of each generation and prepare them for leadership roles at the public's expense. ${ }^{53}$

Education's goal in a republic, Jefferson argued in Notes on the State of Virginia, was "to diffuse knowledge

51. See Jennings L. Wagoner, Jr., Jefferson and Education (Charlottesville, VA: Thomas Jefferson Foundation, 2004), esp. 31-43; Wagoner, Thomas Jefferson and the Education of a New Nation (Bloomington, IN: Phi Delta Kappa Educational Foundation, 1976), 21-39; Cameron Addis, Jefferson's Vision for Education, 1760-1845 (New York: Peter Lang, 2003); Merrill D. Peterson, Jefferson and the New Nation, 145-52; Mayer, Constitutional Thought, 314-19.

52. My discussion draws from Johann N. Neem, "To diffuse knowledge more generally through the mass of the people': Thomas Jefferson on Individual Freedom and the Distribution of Knowledge," in Light and Liberty: Thomas Jefferson and the Power of Knowledge, ed. Robert M. S. McDonald (Charlottesville: University of Virginia Press, 2012), 47-74; Sheldon, Political Philosophy.

53. It is important to note that Jefferson's portrayal of the New England clergy was not accurate and that, in fact, the clergy did much to contribute to the development of citizens' moral, intellectual, and civic capabilities. For education in particular, see Daniel Walker Howe, "Church, State, and Education in the Young American Republic," Journal of the Early Republic 22 (Spring 2002): 1-22. more generally through the mass of the people." ${ }^{54}$ As Richard D. Brown writes, to the Founding Fathers, "being informed was a key ingredient of hegemony, just as ignorance sustained the submissiveness of ordinary people." 55 The concentration of capital produced the concentration of power, whether the capital was economic or cultural in nature. From the republic's perspective, therefore, the best guarantee against tyranny was an educated citizenry. Of all of education's goals, "none is more important, none more legitimate, than that of rendering the people the safe, as they are the ultimate, guardians of their own liberty." 56 Unfortunately, most citizens lacked the capability to act as safe guardians, not because they were immoral, but because they needed the knowledge and skills to be effective in public deliberations. All citizens therefore needed to be educated.

Jefferson proposed dividing Virginia into "hundreds," local districts overseen by local officials. ${ }^{57}$ At this level, all students would receive a free public elementary education. Elementary schools ought to teach those subjects necessary for all people, regardless of their economic origin or their future career. Even those boys and girls destined to be farmers required a broad liberal education. Each citizen must be taught "to judge for himself what will secure or endanger his freedom." 58 But education would go beyond the civic to the whole person. It must "qualify them for [both] their pursuits and duties." 59 In 1818 Jefferson outlined what an ideal elementary education would look like:

give to every citizen the information he needs for the transaction of his own business;

enable him to calculate for himself, and to express and preserve his ideas, his contracts and accounts, in writing;

54. TJ, Notes on the State of Virginia, Query 14, TJW: 271-72.

55. Richard D. Brown, The Strength of a People: The Idea of an Informed Citizenry in America, 1650-1870 (Chapel Hill: University of North Carolina Press, 1996), 47.

56. TJ, Notes, Query 14, TJW: 274. Jefferson's education program, therefore, might be seen as seeking to overcome generations of inherited assumptions about one's role in society-to teach people to think of themselves as free persons capable of making their way in the world. In this sense, Jefferson's educational program may be said to build not only intellectual and moral capability, but the psychology necessary to think of oneself as a free and equal member of civil society. On this point see Appleby, "Thomas Jefferson and the Psychology of Democracy."

57. Ibid., 273.

58. TJ to John Tyler, May 26, 1810, TJW: 1225-27. For a discussion of Jefferson's curriculum, see Pangle and Pangle, Learning of Liberty, 114-24; Jennings L. Wagoner Jr., "'That Knowledge Most Useful to Us': Thomas Jefferson's Conception of Utility in the Education of Republican Citizens," in Thomas Jefferson and the Education of a Citizen, ed. James Gilreath (Washington, DC: Library of Congress, 1999), 115-33.

59. TJ to Peter Carr, Sept. 7, 1814, TJW: 1347-48. 


\begin{abstract}
improve, by reading, his morals and faculties; understand his duties to his neighbors and country, and to discharge with competence the function confided to him by either;

know his rights; to exercise with order and justice those he retains; to choose with discretion the fiduciary of those he delegates; and to notice their conduct with diligence, with candor, and judgment;

And, in general, to observe with intelligence and faithfulness all the social relations under which he shall be placed. ${ }^{60}$
\end{abstract}

The list indicates which capabilities Jefferson thought citizens should develop in order to carry out their public duties and to pursue their private goals. The first two items emphasize what is needed to support oneself in one's chosen career. The third, fourth, and fifth items-improving faculties of reason and moral sense, fulfilling one's social duties, and understanding and defending one's natural and civil rights-were primarily civic, but were also the basis for happiness. The final item suggests that in both private and public life citizens have obligations to others derived from living in society. A graduate of Jefferson's proposed elementary schools would thus have understood and honed the principles of morality, gained reasoning skills, and studied subjects necessary for good citizenship and success in private affairs in order to be better "men and citizens." 61

Jefferson believed that not all people are born with equal intellectual talent. His education program, like his economic program, was designed to prevent the hoarding of capital among the few in order to distribute it widely to the people, and also to permit meritorious individuals, regardless of their origins, to live up to their potential. As he told John Adams in a famous exchange of letters, he wanted to replace an "artificial aristocracy" composed of an inherited elite with a "natural aristocracy" made up of those people with the brightest minds and best morals in their generation. ${ }^{62}$ An artificial aristocracy, Jefferson wrote, is "founded on wealth and birth, without either virtue or talents." In contrast, a society's natural aristocracy, which Jefferson considered "the most precious gift for the instruction, the trusts, and government of society," was made up of those with

60. TJ, "Report of the Commissioners for the University of Virginia," Aug. 4, 1818, TJW: 457-73, at 459.

61. TJ, "Report," 459.

62. Adams to TJ, Sept. 2, 1813, in The Adams-Jefferson Letters: The Complete Correspondence between Thomas Jefferson and Abigail and John Adams, 2 vols. (Chapel Hill: University of North Carolina Press, 1959), 370-72. See also Adams to TJ, Nov. 15, 1813, Ibid., 397-402. the most "virtue and talents," regardless of economic or social origin. Jefferson urged Americans to prevent the emergence of an artificial aristocracy by, first, eradicating primogeniture and entail and, second, by distributing to all Americans the cultural capital that once belonged to the few. ${ }^{63}$

After elementary education, Jefferson proposed a plan that would take the most qualified boys from poor backgrounds and educate them at public expense, ultimately paying for the most meritorious to attend Virginia's then only college, William and Mary. ${ }^{64}$ Jefferson recognized that wealthy boys would still have better access to high school and higher education, but he hoped to break down their monopoly over it. In education, as in his program against primogeniture and entails, Jefferson sought to both develop citizens' capabilities and ensure that elites did not inherit their positions. It was the state's responsibility to offer all citizens real opportunities to enhance their natural capabilities. Jefferson did not discount individual talent and ability, but he believed that these were meaningless unless the state provided the means for each person to make use of them. What one could do mattered as much as what one had the right to do.

\section{RELIGIOUS LIBERTY}

Jefferson's commitment to removing all barriers to religious freedom was unyielding. As in his approach to economic freedom and education, Jefferson first sought to protect a right and then to create, through policy, contexts in which that right could be enjoyed. Thus, as in other areas, Jefferson's first step was to abolish any policies that threatened the right of each person to the freedom of conscience. ${ }^{65}$ "The rights of conscience we never submitted, we could not submit," Jefferson wrote. No human being can give up the right to think. "The legitimate powers of government extend to such acts only as are injurious to others," not to those that concern our own ideas and beliefs. Virginians had started down the path to religious freedom soon after independence. The May 1776 convention that drafted Virginia's first constitution "declared it to be a truth, and a natural right, that the exercise of religion should be free." But Virginians did not follow through on their promise. While the legislature removed statutory support for religion, common law crimes remained; Virginians could be punished for heresy or for denying God. Virginians thus remained in a state of

63. TJ to John Adams, Oct. 28, 1813, TJ_JA: 387-92.

64. Ibid.

65. To Jefferson, the freedom of conscience was not just a political right but a religious precept. See Johann N. Neem, "A Republican Reformation: Thomas Jefferson's Civil Religion and the Separation of Church from State," in A Companion to Thomas Jefferson, ed. Francis D. Cogliano, 91-109. 
"religious slavery." True freedom would come only when the state eradicated all legal limits on "the operations of the mind." 66

As in all freedoms, protecting rights was not enough. The freedom of conscience was a natural right but only public policy could ensure that all citizens enjoyed it. Like economic freedom, religious freedom had to be encouraged, and the key was education. Rather than expose children to religion, Jefferson argued that they must first go to school and learn how to reason. Since religion was often taught from authority, it threatened one's ability to make real choices about one's faith. He argued against "putting the Bible and Testament into the hands of children, at an age when their judgments are not sufficiently matured for religious enquiries." 67 Jefferson worried that young children's minds were being corrupted by religious tutors in the nation's new academies. "I have great confidence in the common sense of mankind in general," Jefferson remarked, "but it requires a great deal to get the better of notions which our tutors have instilled into our minds while incapable of questioning them; \& to rise superior to antipathies strongly rooted." 68

Freedom of conscience, like other freedoms, was premised on the protection of rights and the development of faculties. How and why is one form of belief better than the other, and who is to judge? The answer to the latter question, to Jefferson, was each person's individual conscience. The answer to the former question requires one to be able to choose between competing religions, which, in this case, required reason. Thus in religion, as in the market and in politics, Jefferson combined a negative right-the freedom of conscience-with a positive set of policies. Until children were taught to reason, they could not enjoy their natural right to the freedom of conscience.

\section{JEFFERSON'S RACIAL AND GENDER LIMITS}

If many white Americans lacked the access to the resources-land, economic opportunity, education-to develop their faculties in order to pursue their private happiness and to be effective citizens, enslaved African Americans certainly did. Jefferson recognized that enslaved Americans required access to economic and cultural capital in order to develop their full potential but he refused to believe that black Americans had the same intellectual capabilities as whites and Native Americans. Although Jefferson's approach to liberty could have been used to overcome existing inequalities, in the case of African Americans he justified inequality by citing

66. TJ, Notes on the State of Virginia, Query 17, TJW: 283-85. 67. TJ, Notes on the State of Virginia, Query 14, TJW: 273-74. 68. TJ to Jeremiah Moore, Aug. 14, 1800, TJP 32: 102-3.
African Americans' lack of opportunity as proof of inferiority.

In Notes on the State of Virginia, Jefferson made clear his hostility to slavery. He believed that slavery violated universal natural rights. He also believed that African Americans were equally endowed by nature and nature's God with a moral sense, and thus entitled to basic human respect. Yet, despite his opposition to slavery and his commitment to the rights of enslaved African Americans, he did not consider African Americans suitable for American citizenship. Instead he proffered "the conjecture, that nature has been less bountiful to them in the endowments of the head" than those of the heart (or moral sense). While Jefferson admitted that his belief in black intellectual inferiority was a "conjecture," he went out of the way in Notes to present any evidence he could to support his position. After enumerating myriad reasons why whiteness is preferable to blackness, Jefferson wrote: "Comparing them [black people] by their faculties of memory they are equal to the whites; in reason much inferior, as I think one could scarcely be found capable of tracing and comprehending the investigations of Euclid; and that in imagination they are dull, tasteless, and anomalous." 69

Why did Jefferson devote so much space in Notes to prove his conjecture correct rather than incorrect? He could have argued instead that blacks, if given access to the opportunities he was advocating for poorer whites, would gain the capability to protect and to enjoy their rights and thus become part of the American nation. The answer, as James Oakes writes, is that Jefferson's racism trumped his other beliefs. If intellectual capability was vital to selfgovernment, Jefferson needed to prove that blacks were intellectually inferior and thus incapable of ever becoming full members of the American political nation. The alternative, since Jefferson admitted slavery to be against natural right, was to be shipped back to Africa where African Americans could establish their own republic and be declared "a free and independant people."70

Despite his racism, Jefferson believed that African Americans' human development had been stifled. In 1788 Jefferson wrote that he could not support

69. TJ, Notes, Query 14, comments on slavery TJW: 264-70. For a discussion of the trans-Atlantic intellectual context in which Jefferson made his conclusions, see Michael O'Brien, Conjectures of Order: Intellectual Life and the American South, 2 vols. (Chapel Hill: University of North Carolina Press, 2004), 1: 215-37. See also Winthrop Jordan's classic examination, White over Black: American Attitudes Toward the Negro, 1550-1812 (Chapel Hill: University of North Carolina Press, 1968), 429-81.

70. James Oakes, "Why Slaves Can't Read: The Political Significance of Jefferson's Racism," in Thomas Jefferson and the Education of a Citizen, ed. James Gilreath (Washington, DC: LOC, 1999), 177-92. See also Peter S. Onuf, "'To Declare Them a Free and Independent People': Race, Slavery, and National Identity in Jefferson's Thought," Journal of the Early Republic 18 (1998): 1-46. 
immediate abolition because "to abandon persons whose habits have been formed in slavery is like abandoning children." Jefferson's language suggests that he believed that African Americans' character came from habits formed in the context of slavery-habits that were not innate. He dreamed of trying an experiment settling both Germans and former slaves on fifty-acre plots (i.e., distributing economic capital) and assessing whether African Americans' habits changed once given the capability to participate in the market economy by owning their own property and labor. ${ }^{71}$ Similarly, he wrote in 1785 that while he had "supposed [in Notes] the black man, in his present state" might be inferior, without further knowledge "it would be hazardous to affirm, that, equally cultivated for a few generations, he would not become so."72 In other words, perhaps blacks, like whites, if given the proper access to economic and cultural capital-land and education-could rise to equal levels of achievement.

When Jefferson received a copy of black mathematician Benjamin Banneker's almanac, he wrote Banneker, "No body wishes more than I do to see such proofs as you exhibit, that nature has given to our black brethren, talents equal to those of the other colors of men, and that the appearance of a want of them is owing merely to the degraded condition of their existence, both in Africa \& America." He continued, "I can add with truth, that no body wishes more ardently to see a good system commenced for raising the condition both of their body \& mind to what it ought to be, as fast as the imbecility of their present existence, and other circumstances which cannot be neglected, will admit." 73 It is not clear whether the "other circumstances" refer to the condition of slavery or to racial inferiority, but Jefferson sent a copy of Banneker's almanac to his French friend the Marquis de Condorcet, writing, "I shall be delighted to see these instances of moral eminence so multiplied as to prove that the want of talents observed in them is merely the effect of their degraded condition, and not proceeding from any difference in the structure of the parts on which intellect depends." 74 In these letters Jefferson implied black inferiority could be overcome by access to education and economic opportunity.

Jefferson's racism would not let him accept the possibility of black intellectual equality, however. To admit that the primary challenge facing enslaved Americans was no different than that facing free white Americans-access to land, education, and opportunity - would threaten the entire the Southern

71. TJ to Edward Bancroft, Jan 26, 1788, TJP 14:492-94.

72. TJ to Chastellux, June 7,1785 , TJW: $799-802$, at 801 . See also TJ to Edward Coles, Aug. 25, 1814, TJW: 1343-46.

73. TJ to Benjamin Banneker, Aug. 30, 1791, TJW 982-83.

74. TJ to Condorcet, Aug. 30, 1791, TJP 22: 98-99. social order. ${ }^{75}$ Thus, for example, when sent many years after his infamous lines in Notes a book by the Bishop Henri Gregoire containing samples of the "Literature of the Negroes," Jefferson wrote Gregoire that "no person living wishes more sincerely than I do, to see a complete refutation of the doubts I myself have entertained and expressed on the grade of understanding allotted to them [black people] by nature, and to find that in this respect they are on a par with ourselves."76 Jefferson then wrote privately that Gregoire's “credulity has made him gather up every short story he could find of men of color, (without distinguishing whether black, or of what degree of mixture)." Immediately one senses Jefferson's effort to prove that black intellectual ability must be connected to the introduction of white blood. Jefferson continues that the entire collection did not surpass the successes of the mathematician Banneker. Jefferson then cast doubt on Banneker's own success absent "aid from [the white Quaker Andrew] Ellicot, who was his neighbor and friend." 77 Jefferson was unwilling to admit that blacks, if given access to the same opportunities, would become equal to whites.

In sum, while Jefferson believed that African Americans, like white Americans, were denied the opportunity to develop their potential, his racism led him to support simultaneously efforts to improve African Americans' moral and intellectual faculties and efforts to remove African Americans from the United States. Enslaved blacks no less than poor whites must "be prepared by instruction and habit for self government," Jefferson wrote in $1815 .^{78}$ Yet, Jefferson admitted in January 1826, just months before passing on, that he hoped that African Americans would be expatriated to "the governments of the W.[est] I.[ndies]" because of his "great aversion" to "the mixture of colour here" in the United States. 79 This "aversion" prevented Jefferson from fully extending the logic of his statecraft to African Americans.

Native Americans, to Jefferson, were not innately inferior. Drawing from Scottish thinker Adam Ferguson's theory that all societies develop through distinct

75. On this point, see Harry Watson, "The Man with the Dirty Black Beard: Race, Class, and Schools in the Antebellum South," Journal of the Early Republic 32 (Spring 2012): 1-26; Douglas Egerton, Death or Liberty: African Americans and Revolutionary America (New York: Oxford University Press, 2009), 222-47.

76. TJ to Henri Gregoire, Wash. Feb. 25, 1809, TJW: 1202.

77. TJ to Joel Barlow, Mont., Oct. 8, 1809, TJF 11: 120-24. On this episode, see also Addis, Jefferson's Vision, 12. In an 1814 letter, TJ argues that while blacks' current degraded condition may be due to generations of deprivation, and that one might hope that in time blacks' capabilities will improve, their "amalgamation" with whites now would lead to "a degradation to which no lover of his country, no lover of excellence in the human character can innocently consent." TJ to Coles, Aug. 25, 1814, TJW: 1343-46.

78. TJ to David Barrow, May 1, 1815, TJF 11: 470-71.

79. TJ to William Short, Jan 18, 1826, TJF 12:434. 
stages-moving from the barbaric stage through the agrarian stage to the present stage of polite commercial society-Jefferson concluded that Native Americans were at an earlier stage of development. ${ }^{80}$ In 1824 Jefferson commented that the North American continent exhibited peoples at various stages of development. Starting at the Rocky Mountains and moving east, a traveler would first observe peoples "in the earliest stage of association living under no law but that of nature." Continuing, the traveler would find Indians in "the pastoral state," relying primarily on agriculture. Reaching the American frontier, the traveler would be confronted by "our own semibarbarous citizens, the pioneers of advanced civilization." If the traveler continued east, "he would meet the gradual shades of improving man until he would reach his, as yet, most improved state in our seaport towns." This survey, Jefferson asserted, "is equivalent to a survey, in time, of the progress of man." 81 Once Native Americans became modern, however, Jefferson considered them to be morally and intellectually equal to white Americans and, in fact, worthy of becoming citizens, and even becoming part of the American bloodstream. He told Native Americans that they would "form one people with us, and we shall all be Americans; you will mix with us by marriage, your blood will run in our veins, and will spread with us over this great island." 82

Jefferson urged Native Americans to develop their societies' moral, intellectual, and economic capabilities, and join the American mainstream. Native Americans must choose to modernize. "It," as he put it in 1808, "depends on yourselves alone to become a numerous and great people." ${ }^{83}$ He promised Native Americans that "we consider ourselves as of the same family; we wish to live with them [Native Americans] as one people," but any peaceful resolution of Native American-American tensions required Native Americans to embrace American culture. "We shall, with great pleasure, see your people become disposed to cultivate the earth, to raise herds of the useful animals, and to spin and weave, for their food and clothing." 84

80. McCoy, Elusive Republic, 13-47; Bernard W. Sheehan, Seeds of Extinction: Jeffersonian Philanthropy and the American Indian (Chapel Hill: University of North Carolina Press, 1973); Marvin B. Becker, The Emergence of Civil Society in the Eighteenth Century: A Privileged Moment in the History of England, Scotland, and France (Bloomington, IN: Indiana University Press, 1994). See also Adam Ferguson, An Essay on the History of Civil Society (1767), ed. Fania Oz-Salzberger (Cambridge: Cambridge University Press, 1995).

81. TJ to William Ludlow, Sept. 6, 1824, TJW: 1496-97. My understanding of Jefferson's attitudes toward Native Americans relies heavily on Onuf, Jefferson's Empire, 23-52.

82. TJ to Capt. Hendrick, the Delawares, Mohicans, and Munries, Wash. Dec. 21, 1808, Lipscomb 16: 450-54, at 452.

83. Ibid.

84. TJ to the Brothers Miamis, Powtewatamies, and Weeauks, Jan. 7, 1802, Lipscomb 16: 390-91. See also TJ to Brothers Miamis and Delawares, Jan. 8, 1803, Lipscomb 16: 396-400; TJ,
Jefferson promised to teach Native Americans modern farming and artisanal techniques, distributing to them the cultural capital that they (according to Jefferson) lacked in order to help them improve their economic condition. By refusing to embrace American farming practices, Jefferson believed that Native Americans impoverished themselves and refused to overcome their own cultural deprivation. They denied themselves freedom. Jefferson's approach to freedom, when seen from the Native Americans' perspective, therefore raises many of the concerns about development theory and modernization more generally. ${ }^{85}$ Jefferson was aware of cultural difference but he did not believe that all cultures were equally capable of producing individual freedom. In fact, as Brian Steele argues, Jefferson's study of culture was a form of nationalism: American cultural practices were particularly suited to develop human faculties compared to both Native America and Europe, where, Jefferson believed, human potential languished. $^{86}$

If Native Americans did not embrace the opportunity to join the United States, they would be annihilated. As Secretary of State, Jefferson consistently promoted American interests against Native American tribes that engaged in war with the new United States. He told President George Washington that he hoped that the United States would "give the Indians a thorough drubbing," although he preferred presents and tributes to war. ${ }^{87}$ Jefferson also believed that

Confidential Message on Expedition to the Pacific (to the Senate and HoR), Jan. 18, 1803, TJF 9: 421-34; TJ to Chiefs of the Chickasaw Nation, Minghey, Mataha, and Tishohotana, Mar. 7, 1805, Lipscomb 16: 410-12; TJ to the Wolf and people of the Mandar nation, Dec. 30, 1806, Lipscomb 16: 412-17; TJ to the Chiefs of the Ottawas, Chippewas, Powtewatamies, Wyandots, and Senecas of Sandusky, Apr. 22, 1808, Lipscomb 16: 428-32; TJ to Little Turtle, Chief of the Miamis, Dec. 21, 1808, Lipscomb 16: 440-43; TJ to Captain Hendrick, the Delawares, Mohicans, and Munries, Dec. 21, 1808, Lipscomb 16: 450-54. See also TJ to Brothers of the Choctaw Nation, Dec. 17, 1803, Lipscomb 16: 400-05, at 403. See also TJ to the Chiefs of the Shawnee Nation, Feb. 19, 1807, Lipscomb 16: 421-25, esp. 423-24; TJ to the Chiefs of the Upper Cherokees, May 4, 1808, Lipscomb 16: 432-35; TJ to the Deputies of the Cherokee Upper Towns, Jan. 9, 1809, Lipscomb 16: 455-58. For a discussion of the gendered implications of Jefferson's ideas, in addition to Onuf, Jefferson's Empire, 23-52, see Brian Steele, "Thomas Jefferson's Gender Frontier," Journal of American History 95 (June 2008): 17-42.

85. For a critical perspective on modernization and development, see Michael Latham, Modernization as Ideology: American Social Science and "Nation Building" in the Kennedy Era (Chapel Hill: University of North Carolina Press, 2000). For a discussion of how the American political development framework can learn from this critique and move beyond it, see Orren and Skowronek, Search for American Political Development.

86. Steele, Jefferson and American Nationhood.

87. Secretary of State to the President, Apr. 17, 1791, TJP: 14446; TJ to James Monroe, Apr 17, 1791, TJP 20: 234-36; TJ to Gouverneur Morris, Oct. 15, 1792, TJP 24: 484-85; TJ to David Humphreys, Nov 6, 1792, TJP 24: 587-88. 
Native American lands should be purchased through federal treaties before white settlers inhabited the land. ${ }^{88}$ In addition to force and legal dispossession, Jefferson was willing to use America's soft power to force Native Americans to sell land. As he wrote William Henry Harrison in 1803: "To promote this disposition to exchange lands, which they have to spare and we want, for necessaries, which we have to spare and they want, we shall push our trading uses, and be glad to see the good and influential individuals among them run in debt, because we observe that when these debts get beyond what the individuals can pay, they become willing to lop them off by a cession of lands." ${ }^{89}$ If Native Americans became indebted to the United States, Americans could force them to sell their land to pay off debts, obliging Indians to join the United States and opening up land for American settlers, what Jefferson considered a "coincidence of interests." 90

As president, Jefferson relied on the federal government to provide both carrots and sticks to remove Native Americans from their land. The carrot would be access to trade and the promise of civilization, the stick would be heavy-handed diplomacy and the federal government's ability to use military force. ${ }^{91}$ In assessing Jefferson's approach toward Native Americans, one must remember therefore that even as he professed his commitment to do them justice, even as he promised them access to American cultural capital, his concern was primarily for American citizens who wanted, and from Jefferson's perspective needed, access to the West's land, which Jefferson believed Native Americans-like European aristocrats-claimed more than they could use productively.

Women, Jefferson believed, were intellectually and morally equal to men, but women's sphere was the home. ${ }^{92}$ In Jan Lewis's words, Jefferson and others

88. TJ to Henry Knox, Aug. 10, 1791, TJP 22: 27-28; TJ to William Blount, Aug 12, 1791, TJP: 29; TJ to William Blount, June 6, 1792, TJP 24: 35-36; TJ to Alexander Martin, June 6, 1792, TJP 24: 39.

89. TJ to Governor William H. Harrison, Feb. 27, 1803, TJW: $1117-1120$.

90. TJ to Benjamin Hawkins, Feb. 18, 1803, TJW: 1113-16.

91. On Jefferson's state activism in relation to Native Americans, see Jeffrey Pasley, "Midget on Horseback: American Indians and the History of the American State," Common-place 9 (Oct. 2008); Balogh, A Government Out of Sight, 151-218, esp. 194-200, 205-11. See also Patrick Griffin, American Leviathan: Empire, Nation, and Revolutionary Frontier (New York: Hill \& Wang, 2007), 212-71; Ira Katznelson, "Flexible Capacity: The Military and Early American Statebuilding," in Shaped by War and Trade: International Influences on American Political Development, ed. Ira Katznelson and Martin Shefter (Princeton: Princeton University Press, 2002), 82-110.

92. Steele, "Jefferson's Gender Frontier"; Onuf and Sadosky, Jeffersonian America, 82-102; Jan Lewis, "'The Blessings of Domestic Society': Thomas Jefferson's Family and the Transformation of American Politics," in Jeffersonian Legacies, ed. Peter S. Onuf (Charlottesville: University Press of Virginia, 1993), 109-46. of his generation "shared one of the contradictions of republican thinking": while the domestic sphere was imagined as a site of profound satisfaction and private happiness, it was premised on female "selfeffacement." ${ }^{" 93}$ Although this analysis makes sense to modern ears, Jefferson's generation believed that women and men were by nature different, and thus designed for different roles. A woman's pursuit of her happiness would lead to a different life than a man's. In fact, Jefferson believed that the American Revolution had liberated women as well as men. ${ }^{94}$ When he compared white American women to Native American women and European women, he concluded that American women were better off. He found abhorrent Native Americans' reliance on female agricultural labor because it turned women into drudges, enslaved to their men. American families, in contrast, considered marriage a republican partnership that brought together the natures of woman and man, enabling both to develop their gendered selves. This domestic arrangement also distinguished republican America from aristocratic Europe where, although not slaves, European women had moved out of their natural domestic realm into the public realm, transforming their domestic attractiveness into a public sexuality that undermined female dignity. Jefferson in Paris was consistently shocked by aristocratic women's open sexuality and connected their seductive ways to their unnatural participation in political affairs. By nature chaste, European women, taken outside their natural realm, had to rely on seduction and "voluptuary dress" to gain the better of men, demeaning both men and women. 95

American women, on the other hand, were treated with the respect that their gender deserved and therefore only American society liberated women, Jefferson concluded. Although Jefferson rarely spoke about female education, he advocated public elementary education for girls and was deeply involved in educating his daughter Martha. Thomas consistently reminded Martha that her own happiness would derive from her ability to secure happiness at home. She must serve the men in her family, her father and her husband. Her primary job, however, was to educate the rising generation. If young boys and girls were to grow up with no education, they would then be denied the opportunity to develop their potential. Women needed to be educated, but their natural role required serving others. He thus designed for Martha a serious education program. To Thomas, Martha's education would make her a

93. Lewis, "Blessings," 134.

94. My discussion here is taken from Steele, "Jefferson's Gender Frontier"; Rosemarie Zagarri, "The Rights of Man and Woman in Post-Revolutionary America," William and Mary Quarterly 55 (April 1998): 203-30.

95. TJ to John Banister, Jr., Oct. 15, 1785, TJW: 839. 
good companion, but it was also an insurance policy in case she happened to marry a "blockhead" who lacked the education and intellect to educate properly her children. ${ }^{96}$ As many scholars have noted, "republican motherhood" simultaneously required developing female faculties and, in turn, limiting women's freedom by placing women in service to men. ${ }^{97}$

\section{CONCLUSION}

Although Jefferson's vision had clear limits, he nonetheless offered a wide-ranging argument for the state's role in a democratic society committed to individual freedom. Jefferson believed that a state that did not develop each individual's faculties-his or her potential as a citizen and human being-would fail to live up to the Declaration of Independence's promise of "life, liberty, and the pursuit of happiness."

Central to this project was the wide distribution of wealth and knowledge within and between generations. From this perspective, Jefferson's debate with his Federalist opponents had less to do with whether or not the state was active but whether it created the kind of society that encouraged active citizenship

96. TJ to Marquis Barbe-Barbois, Dec. 5, 1783, as quoted in Steele, "Jefferson's Gender Frontier," 27.

97. Mary Kelley, Learning to Stand and Speak: Women, Education, and Public Life in America's Republic (Chapel Hill: University of North Carolina Press, 2006); Jan Lewis, "The Republican Wife: Virtue and Seduction in the Early Republic," William and Mary Quarterly 44 (Oct. 1987): 689-721; Ruth H. Bloch, "The Gendered Meanings of Virtue in Revolutionary America," in Rethinking the Political: Gender, Resistance, and the State, ed. Barbara Laslett, Johanna Brenner, and Yesim Arat (Chicago: University of Chicago Press, 1995), 11-32; Linda Kerber, Women of the Republic: Intellect and Ideol ogy in Revolutionary America (Chapel Hill: University of North Carolina Press, 1980); Nancy F. Cott, The Bonds of Womanhood: "Woman's Sphere" in New England, 1780-1835 (New Haven: Yale University Press, 1977). and private pursuits of happiness. Jefferson hoped that people would not just be declared free, but that the state would provide citizens opportunities to enjoy their freedom. That, to Jefferson, was what separated republican government from the dynastic monarchical and aristocratic systems that had preceded it. It was also the reason Jefferson believed that every American citizen, as he put it in his inaugural address, "at the call of the law, would fly to the standard of the law, and would meet invasions of the public order as his own personal concern." Americans knew that their government promoted their liberties and, in return, Jefferson thought, they would patriotically come to their nation's defense. ${ }^{98}$

Jefferson's ideas might therefore be considered a precursor to Amartya Sen's and Martha Nussbaum's arguments for a capability approach to freedom. From this perspective, what matters is not just formal rights but whether the members of a society are given real opportunities to develop their talents and pursue a life of their choice. ${ }^{99}$ Jefferson, of course, never read Sen nor Nussbaum, but he believed that rights alone were insufficient-equally important to him was the development of ordinary citizens' capabilities to make the most of the freedoms their rights protected.
98. TJ, "First Inaugural Address" (Mar. 4, 1801), TJW: 493 See Onuf, Jefferson's Empire, Balogh, Government Out of Sight, 114-17, for a discussion of Jefferson's idea of loyalty and government.

99. Sen, Development as Freedom (New York: Knopf, 1999); Sen "Equality of What?" The Tanner Lecture on Human Values (Stanford University, May 22, 1979); Martha C. Nussbaum, Women and Human Development: The Capabilities Approach (Cambridge: Cambridge University Press, 2000); Nussbaum, "Aristotelian Social Democracy," in Liberalism and the Good, ed. R. Bruce, Douglass et al. (New York: Routledge, 1990), 203-52; Nussbaum, "Capabilities as Fundamental Entitlements: Sen and Social Justice," Feminist Economics 09, 2-3 (2003), 33-59; Nussbaum, "Constitutions and Capabilities: 'Perception' against Lofty Formalism," Harvard Law Review 121, 04 (2007), 4-97. Sen has recently used the capabilities approach to offer a new approach to justice in The Idea of Justice (Cambridge, MA: Harvard University Press 2009). For a discussion of the role of the state in promoting individual freedom, historically and sociologically, see Paul Starr, Freedom's Power: The True Force of Liberalism (New York: Basic Books, 2007). 